Bedim, B.P.; Silva, A.P. A concessão de serviços turísticos em Parques Nacionais sob a perspectiva jurídica das parcerias público-privadas. Anais do VIII Congresso Nacional de Ecoturismo e do IV Encontro Interdisciplinar de Ecoturismo em Unidades de Conservação. Revista Brasileira de Ecoturismo, São Paulo, v.4, n.4, 2011, p. 522.

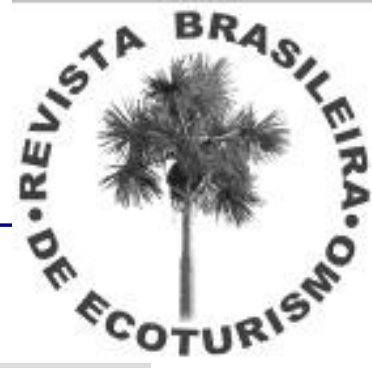

\title{
A CONCESSÃO DE SERVIÇOS TURÍSTICOS EM PARQUES NACIONAIS SOB A PERSPECTIVA JURIIDICA DAS PARCERIAS PÚBLICO-PRIVADAS
}

\section{Bruno Pereira Bedim*, Adriano Pereira da Silva**}

* Universidade Federal de Ouro Preto, ${ }^{* *}$ Faculdade Milton Campos e PUC Minas

E-mails: brunobedim@yahoo.com.br, adriano.silva@sga.pucminas.br

Este trabalho tem como objetivo analisar a concessão de serviços turísticos em Parques Nacionais sob a forma de parcerias público-privadas, discutindo o crescimento paulatino desse tipo de parceria como conseqüência da atual conjuntura política, social, econômica e até mesmo jurídica da sociedade brasileira. Para tanto, procedeu-se à delimitação conceitual e legal do que seja Parceria Público-Privada (PPP), evidenciando essa nova forma de gerir a coisa pública como conseqüência dos imperativos de mercado e, também, como corolário da ineficiência do Estado no sentido de manter o monopólio da gestão dos bens e dos serviços públicos nos dias atuais. Empreendida esta primeira análise, procedeu-se então à abordagem das parcerias público-privadas especificamente no âmbito dos Parques Nacionais, apresentando exemplos brasileiros de implantação de tais parcerias. Por fim, realizou -se uma apreciação crítica sobre 0 atual contexto dos Parques Nacionais, apresentando sugestões de medidas que possam contribuir para melhorar as suas condições de infraestrutura e serviços disponíveis aos visitantes, de modo que os Parques alcancem, o máximo possível, os fins que lhes foram conferidos pela legislação pertinente.

Palavras-chave: Parceria Público-Privada; Parques Nacionais; Turismo. 